\title{
The role of endothelin-1 and its receptor blockers on the liver function
}

\author{
Łukasz Michalski, Paulina Kleniewska, Aleksandra Piechota-Polańczyk and Anna Gorąca \\ Department of Cardiovascular Physiology, Medical University of Łódź, Mazowiecka 6/8, 92-215 Łódź, Poland
}

\begin{abstract}
Endothelin-1 (ET-1) was first described by Yanagisawa et al. (1988) as a 21 -amino acid peptide present in the extract from the aorta endothelial cells. It is known that ET-1 is one of the most potent vasoconstrictor compounds and also causes proliferation of many of the vascular cells involved in vascular remodeling. This peptide exerts its action through interactions with its membrane receptors $-\mathrm{ET}_{\mathrm{A}}$ and $\mathrm{ET}_{\mathrm{B}}$. These receptors are expressed in the vascular smooth muscle cells, endothelial cells, intestines and the brain. Secretion of ET-1 results in long-lasting vasoconstriction, increased blood pressure and, in turn, overproduction of free radicals. As dysregulation of the endothelin system is an important factor in the pathogenesis of several diseases including atherosclerosis, hypertension and endotoxic shock, the $\mathrm{ET}_{\mathrm{A}}$ and $\mathrm{ET}_{\mathrm{B}}$ receptors are attractive therapeutic targets for treatment of these disorders. Recently, several clinical trials have provided evidence that ET-1 receptor antagonism influences liver function and has therapeutic potential in the treatment of liver impairment. Therefore, this review summarizes recent clinical trials on the role of ET-1 receptor blockers with respect to the modulation of liver function.
\end{abstract}

Key words: Endothelin-1 - Endothelin-1 receptor blockers — Liver function

\begin{abstract}
Abbreviations: ECE, endothelin-converting enzymes; ET-1, endothelin-1; $\mathrm{ET}_{\mathrm{A}}$, endothelin receptor type $\mathrm{A} ; \mathrm{ET}_{\mathrm{B}}$, endothelin receptor type $\mathrm{B}$; $\mathrm{PAH}$, pulmonary arterial hypertension; $\mathrm{PPH}$, portopulmonary hypertension.
\end{abstract}

\section{Introduction}

Endothelin-1, first described by Yanagisawa et al. (1989), is a 21-amino acid residue peptide whose structure is similar to sapharotoxins synthesized by some snakes and scorpions (Goraca 2002). So far three endothelin isoforms have been characterized: endothelin-1 (ET-1), endothelin-2 (ET-2), and endothelin-3 (ET-3) involved in diverse physiological and pathophysiological events. The genes that encode them are localized respectively on the 6th, 1st and 20th chromosomes. Endothelins are produced primarily in the endothelium. In the endothelium, ET-1 is predominantly released abluminally toward the vascular smooth muscle, suggesting a paracrine role. ET-1 is also produced by other cells including leukocytes, macrophages, smooth muscle

Correspondence to: Anna Gorąca, Department of Cardiovascular Physiology, Medical University of Łódź, Ul. Mazowiecka 6/8, 92215 Łódź, Poland

E-mail: anna.goraca@umed.lodz.pl cells, cardiomyocytes, mesangial cells, fibroblasts, blood platelets, hepatocytes and its synthesis is regulated in an autocrine. ET-2 is released by myocardial cells, placental cells, the uterus, kidneys and intestines, while ET-3 was found in the digestive system, central nervous system, lungs and kidneys (King 2008).

Endothelin synthesis starts with inactive 212 amino acid, pre-pro endothelin (pre-pro ET-1). Pre-pro ET-1 is processed intracellularly by furin-like proteases to pro-endothelin (big ET-1) which consists of $38-40$ amino acids and has little or no biological effect. Next, big ET-1 is cleaved at Trp-21Val/Ile-22 by specific endothelin-converting enzymes (ECE), to yield a 21-amino acid peptide, which is biologically active (Kojima et al. 2001; Rockey 2003). This would explain why proendothelins excreted in the plasma accounted only for $1 \%$ of the terminal level of ET-1. Endothelin-converting enzymes often become a target for therapy in certain diseases connected with elevated endothelin level (Goldie 1999; Lorenzo et al. 2001). So far, three distinct ECE subtypes have been described: ECE-1, ECE-2 and ECE-3. Although 
ECE-1 seems to be the specific enzyme for big ET-1 and ECE-2 for big ET-2, both of these enzymes indicate a greater affinity for big ET-1. This would explain why experimental animals with decreased ECE-1 and ECE-2 levels still have high ET-1 levels. This finding might also suggest that other enzymes are engaged in the terminal level of ET-1 (Lorenzo et al. 2001).

ET-1 has been previously described as a compound that takes part in many biological processes such as cell proliferation or connective tissue cell differentiation. Moreover, ET-1 appears to play an important role in stellate cell activation, stimulating their activation and fibrogenic phenotype (Takashimizu et al. 2011). An imbalance in endothelin levels can be also observed in the case of certain cardiovascular system diseases such as hypertension or systemic sclerosis, which lead to liver dysfunction (Rockey et al. 1996, 1998; Goldie 1999; Lorenzo et al. 2001; Ergul 2002).

\section{Liver distribution and physiological role of ET-1 receptors}

Endothelin-1 effects are mediated by the activation of endothelin $\mathrm{ET}_{\mathrm{A}}$ or $\mathrm{ET}_{\mathrm{B}}$ receptors. In the liver, $\mathrm{ET}_{\mathrm{A}}$ receptors are found on vascular smooth muscle cells and hepatic stellate cells (Rockey et al. 1996), while $\mathrm{ET}_{\mathrm{B}}$ receptors are localized on sinusoidal endothelial cells, hepatic stellate cells and Kupffer cells (Kojima et al. 2001; Motte et al. 2006; Feng et al. 2009). ET $\mathrm{B}_{\mathrm{B}}$ receptors are divided into two subtypes: $\mathrm{ET}_{\mathrm{B} 1}$ and $\mathrm{ET}_{\mathrm{B} 2}$.

$\mathrm{ET}_{\mathrm{A}}$ and $\mathrm{ET}_{\mathrm{B}}$ receptors belong to a $\mathrm{G}$ protein-coupled group whose stimulation leads to the activation of inositol-3 phosphate $\left(\mathrm{IP}_{3}\right)$ and diacylglycerol (DAG) (phospholipase C-mediated hydrolysis of polyphosphoinositol 4,5-bisphosphate $\left(\mathrm{PIP}_{2}\right) \cdot \mathrm{IP}_{3}$ increases the cytoplasmic calcium level while DAG ameliorates the mitogen-activated protein kinase (MAPK) concentration ( $\mathrm{Li}$ et al. 2010). Thus, stimulation of $\mathrm{ET}_{\mathrm{A}}$ and $\mathrm{ET}_{\mathrm{B} 2}$ receptors causes vasoconstriction, inflammation and fibrosis, while activation of $\mathrm{ET}_{\mathrm{B} 1}$ receptors leads to $\mathrm{NO}$, prostacyclin $\mathrm{I}_{2}$ and endothelial hyperpolarizing factor release, which is presumably important in the maintenance of sinusoidal relaxation (Lavelle et al. 2009) (Fig. 1).

Recently, Chen et al. (2011) showed that up-regulation of $\mathrm{ET}_{\mathrm{A}}$ receptors on hepatic stellate cells after the small-for-size liver transplantation reduces the sinusoidal perfusion rate and leads to graft injury. They proposed transient portal venous hypertension as a possible mechanism underlying liver dysfunction.

\section{ET-1 and ET-1 receptor antagonists influence on liver blood flow}

The liver is an organ capable of compensating portal blood flow to keep the portal pressure at a normal level of 5-10 mmHg (Cichoz-Lach et al. 2008). Stable pressure is a result of vascular bed response to vasodilatators like nitric oxide and vasoconstrictors, mainly ET-1 and cyclooxygenase-derived prostaglandins. ET-1 binding sites have been identified in the endothelial cells of hepatic sinusoids, portal vein and hepatic central veins (Gondo et al. 1993). ET-1 has been reported to activate phospholipase $\mathrm{C}$ and membrane ion channels, thus provoking the stellate cell constriction in the sinusoid (Iizuka et al. 2011). This effect is mainly mediated by $\mathrm{ET}_{\mathrm{A}}$ receptors. Recently, Iizuka et al. (2011) indicated that ET-1-stimulated hepatic stellate cells cause hepatic sinusoidal constriction through both $\mathrm{Ca}(2+)$-dependent (myosin light-chain kinase - MYLK or MLCK pathway) and $\mathrm{Ca}(2+)$-sensitization mechanisms (CPI-17 and myosin phosphatase targeting protein 1 - MYPT1 pathways) in the cirrhotic liver. It has been also shown that during cirrhosis, both ET-1 and $\mathrm{ET}_{\mathrm{A}}$ receptors levels are up-regulated (Bauer et al. 1994; Morawietz et al. 2000; Shi-Wen et al. 2001). Moreover, Chan et al. (2004) indicated that blockage of $\mathrm{ET}_{\mathrm{A}}$ receptors alone or simultaneous blockage of $\mathrm{ET}_{\mathrm{A}}$ and $\mathrm{ET}_{\mathrm{B}}$ receptors suppressed ET-1-induced portal vein vasoconstriction, whereas stimulation of $\mathrm{ET}_{\mathrm{B}}$ receptors with $\mathrm{ET}-1$ causes intrahepatic vasoconstriction (Bauer et al. 2000). The vasoconstriction effect is more intense in cirrhotic rats, suggesting that $\mathrm{ET}_{\mathrm{B}}$ receptors may mediate vasoconstriction in the portal vascular bed in cirrhotic animals (Khimji et al. 2001). Portopulmonary hypertension (PPH) refers to the development of pulmonary arterial hypertension (PAH) in patients with portal hypertension, a complication occurring in patients with cirrhosis. Plasma levels of ET-1 are elevated (up to 10-fold) in patients with PAH (CartinCeba et al. 2011). Tsiakalos et al. (2011) have proven that patients with $\mathrm{PPH}$ had a significantly higher plasma level of ET-1 than cirrhotic patients without PPH. Takashimizu et al. (2011) have described that ET-1 action via the $\mathrm{ET}_{\mathrm{A}}$ receptor may be involved in the mechanism of portal hypertension in liver cirrhosis.

\section{Endothelin-1 receptor antagonists influence on liver biochemistry}

Since the discovery of ET-1, numerous different endothelin receptor antagonists, both specific and non-specific, have been developed. Recently, the Food and Drug Administration (FDA) agency has approved some of them for the treatment of PAH - ambisentran, sitaxentan (Hrometz et al. 2008); idiopathic pulmonary fibrosis and digestive system ulceration - bosentan (Kähler et al. 2011); hepatic ischemia/reperfusion injury - tezosentan (Farmer et al. 2008); systemic hypertension - darusentan (Hynenen and Khalil 2006; Meri et al. 2006). 


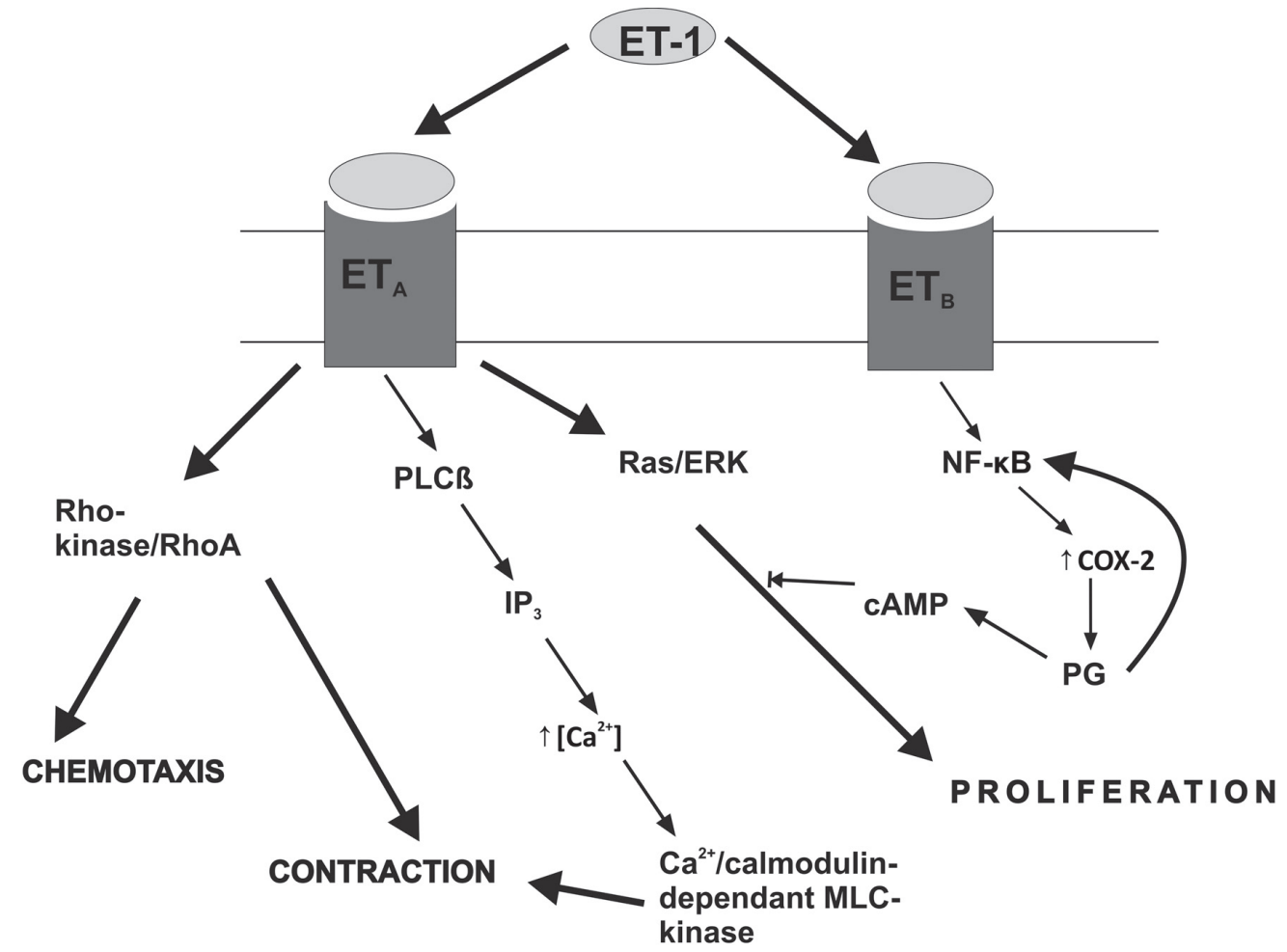

Figure 1. Pleiotropic effect of ET-1 on hepatic stellate cells through different receptors. COX-2, cyclooxygenase type 2; DAG, diacylglycerol; ET-1, endothelin-1; $\mathrm{ET}_{\mathrm{A}}$, endothelin receptor type $\mathrm{A} ; \mathrm{ET}_{\mathrm{B}}$, endothelin receptor type $\mathrm{B} ; \mathrm{IP}_{3}$, inositol-3 phosphate; MLC-kinase, myosin light chain kinase; NF- $\kappa$ B, nuclear factor kappa B; PCL $\beta-1$, phosphatidylinositol-4,5-bisphosphate phosphodiesterase beta; Ras-ERK, subunits of mitogen activated protein kinases (MAPK) pathway; PG, prostaglandin. Based on: Hui and Friedman (2003).

Bosentan and sitaxentan are sulphonamide analogues with the $\mathrm{ET}_{\mathrm{A}}$ to $\mathrm{ET}_{\mathrm{B}}$ receptors affinity ratio $40: 1$ for bosentan and $6000: 1$ for sitaxentan; ambrisentan is a nonsulphonamide, propanoic acid derivatives specified as a $\mathrm{ET}_{\mathrm{A}}$ receptor blocker; while tezosentan is a non-selective $\mathrm{ET}_{\mathrm{A}}$ and $\mathrm{ET}_{\mathrm{B}}$ receptors antagonist designed as a therapy for $\mathrm{pa}$ tients with acute heart failure, however it is mostly removed by the liver with the bile (Dupuis and Hoeper 2005, 2007; Dingemanse et al. 2006;).

Recently performed clinical trials on patients prescribed endothelin receptor antagonists investigated their effects on liver biochemical parameters and presented contradictory results. The study of Hoeper et al. (2007) performed on patients with Child A cirrhosis and severe $\mathrm{PPH}$ prescribed bosentan (started at a dose of $62.5 \mathrm{mg}$ for 4 weeks followed by $125 \mathrm{mg}$ as a target maintenance dose) for one year indicated no changes in hepatic biochemical parameters. Moreover, in their trial patients with POPH treated with bosentan had a better outcome than patients treated with inhaled iloprost (given six times daily at a dose of $5 \mathrm{mg}$ through the mouthpiece using standard nebulisers). The survival rates at 1,2 and 3 years were $94 \%, 89 \%$ and $89 \%$, respectively, in the bosentan group, and $77 \%, 62 \%$ and $46 \%$, respectively, in the iloprost group (Hoeper et al. 2007). Bosentan was also well tolerated by the majority of patients (in one patient, hepatic aminotransferases increased to more than 3-times the upper level as compared to normal, but it normalised when the bosentan dose was reduced from $125 \mathrm{mg}$ to $62.5 \mathrm{mg}$ ). However, the use of bosentan in patients with $\mathrm{PPH}$ has been questioned, since bosentan has a well-known hepatotoxic potential and aminotransferase elevations have been reported in $7-12 \%$ of patients exposed to this drug. Humbert et al. (2007) have indicated that bosentan treatment was not recommended in patients with moderately or severely impaired liver function. No new safety was discovered and the rate of occurrence and severity of elevated aminotransferases observed in Tracleer post-marketing surveillance (PMS) program with 3416 patient-years of treatment matched that originally seen in the clinical trial setting with 59 patient-years of treatment (Humbert et al. 2007). The selective endothelin receptor antagonists, sitaxentan and ambrisentan, are in general associated with less risk of adverse liver reactions. Lavelle et al. (2009) presented two patients with severe hepatotoxicity, one of them fatal, occurring 4 months after the beginning of sitaxentan therapy. 
In "Tracleer" studies, the mean age of patients was about 49 years. About $80 \%$ of patients were female, and about $80 \%$ were Caucasian. Patients had been diagnosed with pulmonary hypertension for a mean of 2.4 years. The benefit/risk balance of bosentan/Tracleer has not been established at early stage of the disease e.g. patients with grade I and grade II functional status. Data do not support the use of bosentan in patients with grade IV functional status. Clinical experience has not identified differences in responses between elderly and younger patients (safety and efficacy have not been established in children under the age of 12 years). There is limited experience in patients with a body weight below $40 \mathrm{~kg}$ (only 2 patients were included in the clinical trials). In summary, it is not known whether bosentan's pharmacokinetics is influenced by gender, body weight, race or age. Barst et al. (2004) in a randomized, double-blind, placebo-controlled trial incorporating patients with pulmonary arterial hypertension who took sitaxentan (in two doses of $100 \mathrm{mg}$ and $300 \mathrm{mg}$ orally once daily for 12 weeks) noted an increased aminotransferase level. The incidence of liver function abnormalities was much lower for the 100-mg dose compared with the 300-mg dose, suggesting a distinct dose response for safety and tolerability. However, lately Safdar (2011) in a retrospective study of patient from STRIDE studies switching from sitaxentan (100 mg oral daily) to ambrisentan ( $5 \mathrm{mg}$ oral daily) for another year of treatment showed no increase in aminotransferase blood level. This data suggest that switching from a selective $\mathrm{ET}_{\mathrm{A}}$ to another selective $\mathrm{ET}_{\mathrm{A}}$ may be safe. Similarly, Catrin-Ceba et al. (2011) in prospective study of 18 patients with portopulmonary hypertension treated with ambrisentan (5 mg orally daily for 4 weeks, with a dosage increase to $10 \mathrm{mg}$ orally daily thereafter in the absence of side effects) showed no difference in aminotransferases and bilirubin concentration.

\section{The safety and effectiveness of ambrisentan has not been studied in children}

The cause underlying an increase in aminotransferase blood level after the ET-1 receptor antagonist administration is unknown. Nevertheless, bosentan has been speculated to influence hepatocanalicular bile salt export pump causing intracellular accumulation of cytotoxic bile salts resulting in liver cell damage (Fattinger et al. 2001). Furthermore, sitaxentan inhibits the hepatic enzyme cytochrome P450 CYP2P9, which may lead to increased episodes of bleeding in patients taking anticoagulant therapy (Barst et al. 2004).

Therefore, following the results of STRIDE-2 and STRIDE-2X randomized clinical trials comparing bosentan and sitxentan therapy in PAH patients, the sitaxentan therapy occurred to have a lower incidence of hepatotoxicity than bosentan (Barst et al. 2004, 2006; Benza et al. 2008). Recently,
Kähler et al. (2011) described a protective effect of sitaxentan therapy in patients with PPH and Child A cirrhosis. In their study, 3 month therapy with sitaxentan ( $100 \mathrm{mg} /$ day orally) had no effect on liver enzymes (Kawada et al. 1993).

Although not frequently used with cirrhotic patients tezosentan and its influence on liver impairment was widely studied by Dingemanase et al. (Dingemanse et al. 2004, 2006 and 2009); their results indicated that increased bilirubin levels observed in patients with mild liver impairment or cirrhosis influence tezosentan pharmacokinetics and prolong tozosentan exposure. Despite no adverse effects observed in Dingemanase et al. studies, tezosentan dose reduction in patients with liver impairement and serum blilrubin level above $3.5-12 \mathrm{mg} / \mathrm{dl}$ has been recommended (Dingemanse et al. 2004 and 2009).

Apart from endothelin receptor antagonists already approved for the medical usage, there is a group of endothelin receptor blockers that undergo clinical experimental studies. Recently, Bruderer et al. (2011) published an exploratory study results presenting the effect of clozosentan, a selective $\mathrm{ET}_{\mathrm{A}}$ receptor antagonist, on mild, moderate and severe liver cirrhosis; in their study clozosentan treatment ( $1 \mathrm{mg} / \mathrm{h}$ for a period of 6 hours) increased the severity of liver impairment in patients with moderate and severe liver damage.

Therefore, additional clinical trials need to be performed to evaluate possible clinical usefulness of clozosentan.

\section{Conclusion}

The understanding of ET-1 and its blockers on the liver function has not been fully understood yet. For the moment we are left with compelling experimental evidence that endothelin may be involved in many vascular abnormalities in patients with liver disorders e.g. portopulmonary hypertension and liver cirrhosis. Therefore, whether inhibition of $\mathrm{ET}_{\mathrm{A}}$ and/or $\mathrm{ET}_{\mathrm{B}}$ receptors responses proves to be therapeutically useful may depend on the balance between systemic and local effects of ET-1 receptor blockers in different patients.

Acknowledgements. The study was supported by grant number 503/0-079-03/503-01 from the Medical University of Łódź.

\section{References}

Barst R. J., Langleben D., Badesch D., Frost A., Lawrence E. C., Shapiro S., Naeije R., Galie N. (2006): Treatment of pulmonary arterial hypertension with the selective endothelin-A receptor antagonist sitaxsentan. J. Am. Coll. Cardiol. 47, 2049-2056

http://dx.doi.org/10.1016/j.jacc.2006.01.057 
Barst R. J., Langleben D., Frost A. Horn E. M., Oudiz R., Shapiro S., McLaughlin V., Hill N., Tapson V. F., Robbins I. M., Zwicke D., Duncan B., Dixon R. A., Frumkin L. R. (2004): Sitaxsentan therapy for pulmonary arterial hypertension. Am. J. Respir. Crit. Care. Med. 169, 441-447 http://dx.doi.org/10.1164/rccm.200307-957OC

Bauer M., Bauer I., Sonin N. V. Kresge N., Baveja R., Yokoyama Y., Harding D., Zhang J. X., Clemens M. G. (2000): Functional significance of endothelin $\mathrm{B}$ receptors in mediating sinusoidal and extrasinusoidal effects of endothelins in the intact rat liver. Hepatology 31, 937-947 http://dx.doi.org/10.1053/he.2000.5922

Bauer M., Zhang J. X., Bauer I. Clemens M. G. (1994): ET-1 induced alterations of hepatic microcirculation: sinusoidal and extrasinusoidal sites of action. Am. J. Physiol. 267, G143-149

Benza R. L., Barst R. J., Galie N., Frost A., Girgis R. E., Highland K. B., Strange C., Black C. M., Badesch D. B., Rubin L., Fleming T. R., Naeije R. (2008): Sitaxsentan for the treatment of pulmonary arterial hypertension: a 1-year, prospective, open-label observation of outcome and survival. Chest 134, 775-782 http://dx.doi.org/10.1378/chest.07-0767

Bruderer S., Detishin V., Tsvitbaum N., Dingemanse J. (2011): Influence of different degrees of liver impairment on the pharmacokinetics of clazosentan. Br. J. Clin. Pharmacol. 71, $52-60$ http://dx.doi.org/10.1111/j.1365-2125.2010.03804.x

Cartin-Ceba R., Swanson K., Iyer V., Wiesner R. H., Krowka M. J. (2011): Safety and efficacy of ambrisentan for the treatment of portopulmonary hypertension. Chest $139,109-114$ http://dx.doi.org/10.1378/chest.10-0574

Chan C. C., Wang S. S., Lee F. Y., Chang F. Y., Lin H. C., Hou M. C., Huang H. C., Lee S. D. (2004): Effects of endothelin-1 on portal-systemic collaterals of common bile duct-ligated cirrhotic rats. Eur. J. Clin. Invest. 34, 290-296 http://dx.doi.org/10.1111/j.1365-2362.2004.01336.x

Chen W., Liang L., Ma T., Li J., Li J., Xu G., Zhang Y., Bai X., Liang T. (2011): The role of hepatic stellate cells on graft injury after small-for-size liver transplantation. J. Gastroenterol. Hepatol. 26, $1659-1668$ http://dx.doi.org/10.1111/j.1440-1746.2011.06781.x

Cichoz-Lach H., Celiński K., Słomka M., Kasztelan-Szczerbińska B. (2008): Pathophysiology of portal hypertension. J. Physiol. Pharmacol. 59, 231-238

Dingemanse J., Gunawardena K. A., van Giersbergen P. L. (2006): Comparison of the pharmacokinetics, pharmacodynamics and tolerability of tezosentan between caucasian and Japanese subjects. Br. J. Clin. Pharmacol. 61, 405-413 http://dx.doi.org/10.1111/j.1365-2125.2006.02586.x

Dingemanse J., Halabi A., van Giersbergen P. L. (2009): Influence of liver cirrhosis on the pharmacokinetics, pharmacodynamics, and safety of tezosentan. J. Clin. Pharmacol. 49, $455-464$ http://dx.doi.org/10.1177/0091270008330157

Dingemanse J., van Giersbergen P. L. (2004): Influence of mild liver impairment on the pharmacokinetics of tezosentan, a drug excreted unchanged into bile. Br. J. Clin. Pharmacol. 57, 344-348 http://dx.doi.org/10.1046/j.1365-2125.2003.01987.x
Dupuis J., Hoeper M. M. (2008): Endothelin receptor antagonists in pulmonary arterial hypertension. Eur. Respir. J. 31, 407-415 http://dx.doi.org/10.1183/09031936.00078207

Ergul A. (2002): Endothelin-1 and endothlein receptor antagonists as potential cardiovascular therapeutic agents. Pharmacotherapy 22, 54-65 http://dx.doi.org/10.1592/phco.22.1.54.33505

Farmer D. G., Kaldas F., Anselmo D., Katori M, Shen X. D., Lassman C., Kaldas M., Clozel M., Busuttil R. W., Kupiec-Weglinski J. (2008): Tezosentan, a novel endothelin receptor antagonist, markedly reduces rat hepatic ischemia and reperfusion injury in three different models. Liver Transpl. 14, 1737-1744 http://dx.doi.org/10.1002/lt.21621

Fattinger K., Funk C., Pantze M., Weber C., Reichen J., Stieger B., Meier P. J. (2001): The endothelin antagonist bosentan inhibits the canalicular bile salt export pump: a potential mechanism for hepatic adverse reactions. Clin. Pharmacol. Ther. 69, 223-231 http://dx.doi.org/10.1067/mcp.2001.114667

Feng H. Q., Weymouth N. D., Rockey D. C. (2009): Endothelin antagonism in portal hypertensive mice: implications for endothelin receptor-specific signaling in liver disease. Am. J. Physiol. Gastrointest. Liver Physiol. 297, G27-33 http://dx.doi.org/10.1152/ajpgi.90405.2008

Goldie R. G. (1999): Endothelins in health and disease: an overview. Clin. Exp. Pharmacol. Physiol. 26, 145-148 http://dx.doi.org/10.1046/j.1440-1681.1999.03014.x

Gondo K., Ueno T., Sakamoto M., Sakisaka S., Sata M., Tanikawa K. (1993): The endothelin-1 binding site in rat liver tissue: light- and electron-microscopic autoradiographic studies. Gastroenterology 104, 1745-1749

Goraca A. (2002): New views on the role of endothelin. Endocrine Regulations 36, 161-167

Hoeper M. M., Halank M., Marx C., Hoeffken G., Seyfarth H. J., Schauer J., Niedermeyer J., Winkler J. (2005): Bosentan therapy for portopulmonary hypertension. Eur. Respir. J. 25, 502-508 http://dx.doi.org/10.1183/09031936.05.00080804

Hoeper M. M., Seyfarth H. J., Hoeff ken G., Wirtz H., Spiekerkoetter E., Pletz M. W., Welte T., Halank M. (2007): Experience with inhaled iloprost and bosentan in portopulmonary hypertension. Eur. Respir. J. 30, 1096-1102 http://dx.doi.org/10.1183/09031936.00032407

Hrometz S. L., Shields K. M. (2008): Role of ambrisentan in the management of pulmonary hypertension. Ann. Pharmacother. 42, 1653-1659 http://dx.doi.org/10.1345/aph.1L014

Hui A. Y., Friedman L. (2003): Molecular basis of hepatic fibrosis. Expert. Rev. Mol. Med. 5, 1-23 http://dx.doi.org/10.1017/S1462399403005684

Humbert M., Segal E. S., Kiely D. G., Carlsen J., Schwierin B., Hoeper M. M. (2007): Results of European post-marketing surveillance of bosentan in pulmonary hypertension. Eur. Respir. J. 30, 338-344 http://dx.doi.org/10.1183/09031936.00138706

Iizuka M., Murata T., Hori M., Ozaki H. (2011): Increased contractility of hepatic stellate cells in cirrhosis is mediated by enhanced $\mathrm{Ca} 2+$-dependent and $\mathrm{Ca} 2+$-sensitization pathways. Am. J. Physiol. Gastrointest. Liver Physiol. 300, G1010-1021 
http://dx.doi.org/10.1152/ajpgi.00350.2010

Kawada N., Tran-Thi T. A., Klein H., Decker K. (1993): The contraction of hepatic stellate (Ito) cells stimulated with vasoactive substances. Possible involvement of endothelin-1 and nitric oxide in the regulation of the sinusoidal tonus. Eur. J. Biochem. 213, 815-823 http://dx.doi.org/10.1111/j.1432-1033.1993.tb17824.x

Kähler C. M., Graziadei I., Vogelsinger H., Desole S., Cima K., Vogel W. (2011): Successful treatment of portopulmonary hypertension with the selective endothelin receptor antagonist Sitaxentan. Wien. Klin. Wochenschr. 123, 248-252 http://dx.doi.org/10.1007/s00508-011-1540-4

King T. E. (2008): Bosentan for idiopathic pulmonary fibrosis. Curr. Opin. Investig. Drugs 9, 1171-1179

Khimji A. K., Rockey D. C. (2011): Endothelin and hepatic wound healing. Pharmacol. Res. 63, 512-518 http://dx.doi.org/10.1016/j.phrs.2011.03.005

Kojima H., Sakurai S., Kuriyama S., Yoshiji H., Imazu H., Uemura M., Nakatani Y., Yamao J., Fukui H. (2001): Endothelin-1 plays a major role in portal hypertension of biliary cirrhotic rats through endothelin receptor subtype B together with subtype A in vivo. J. Hepatol. 34, 805-811 http://dx.doi.org/10.1016/S0168-8278(01)00045-9

Lavelle A., Sugrue R., Lawler G., Mulligan N., Kelleher B., Murphy D. M., Gaine S. P. (2009): Sitaxentan-induced hepatic failure in two patients with pulmonary arterial hypertension. Eur. Respir. J. 34, 770-771 http://dx.doi.org/10.1183/09031936.00058409

Li J., Kuruba R., Wilson A., Gao X., Zhang Y., Li S. (2010): Inhibition of endothelin-1-mediated contraction of hepatic stellate cells by FXR ligand. PLoS. One. 5, e13955 http://dx.doi.org/10.1371/journal.pone.0013955

Lorenzo M. N., Khan R. Y., Wang Y., Tai S. C., Chan G. C., Cheung A. H., Marsden P. A. (2001): Human endothelin converting enzyme-2 (ECE-2): characterization of mRNA species and chromosomal localization. Biochem. Biophys. Acta 1522, 46-52 http://dx.doi.org/10.1016/S0167-4781(01)00283-4

Hynenen M. M., Khalil R. A. (2006): The vascular endothelin system in hypertension - recent patents and discoveries. Recent. Pat. Cardiovasc. Drug. Discov. 1, 95-108 http://dx.doi.org/10.2174/157489006775244263

Morawietz H., Talanow R., Szibor M., Rueckschloss U., Schubert A., Bartling B., Darmer D., Holtz J. (2000): Regulation of the endothelin system by shear stress in human endothelial cells. J. Physiol. 525, 761-770 http://dx.doi.org/10.1111/j.1469-7793.2000.00761.x

Motte S., McEntee K., Naeije R. (2006): Endothelin receptor antagonists. Pharmacol. Ther. 110, 386-344 http://dx.doi.org/10.1016/j.pharmthera.2005.08.012

Rockey D. C. (2003): Vascular mediators in the injured liver. Hepatology 37, 4-12 http://dx.doi.org/10.1053/jhep.2003.50044

Rockey D. C., Chung J. J. (1998): Reduced nitric oxide production by endothelial cells in cirrhotic rat liver: endothelial dysfunction in portal hypertension. Gastroenterology 114, 344-351 http://dx.doi.org/10.1016/S0016-5085(98)70487-1

Rockey D. C., Fouassier L., Chung J. J., Carayon A., Vallee P., Rey C., Housset C. (1998): Cellular localization of endothelin-1 and increased production in liver injury in the rat: potential for autocrine and paracrine effects on stellate cells. Hepatology $27,472-480$ http://dx.doi.org/10.1002/hep.510270222

Rockey D. C., Weisiger R. A. (1996): Endothelin induced contractility of stellate cells from normal and cirrhotic rat liver: implications for regulation of portal pressure and resistance. Hepatology 24, 233-240

http://dx.doi.org/10.1002/hep.510240137

Safdar Z. (2011): Effect of transition from sitaxsentan to ambrisen$\tan$ in pulmonary arterial hypertension. Vasc. Health. Risk. Manag. 7, 119-124 http://dx.doi.org/10.2147/VHRM.S15026

Shi-Wen X., Denton C. P., Dashwood M. R., Holmes A. M., Bou-Gharios G., Pearson J. D., Black C. M., Abraham D. J. (2001): Fibroblast matrix gene expression and connective tissue remodeling: role of endothelin-1. J. Invest. Dermatol. 116, 417-425 http://dx.doi.org/10.1046/j.1523-1747.2001.01256.x

Takashimizu E. S., Kojima S., Nishizaki Y., Kagawa T., Shiraishi K., Mine T., Watanabe N. (2011): Effect of Endothelin a Receptor Antagonist on Hepatic Hemodynamics in Cirrhotic Rats. Implications for Endothelin-1 in Portal Hypertension. Tokai. J. Exp. Clin. Med. 36, 37-43

Tsiakalos A., Hatzis G., Moyssakis I., Karatzaferis A., Ziakas P. D., Tzelepis G. E. (2011): Portopulmonary hypertension and serum endothelin levels in hospitalized patients with cirrhosis. Hepatobiliary Pancreat. Dis. Int. 10, 393-398 http://dx.doi.org/10.1016/S1499-3872(11)60066-0

Yanagisawa M., Inoue A., Takuwa Y., Mitsui Y., Kobayashi M., Masaki M. (1989): The human preproendothelin-1 gene: possible regulation by endothelial phosphoinositide turnover signaling. J. Cardiovasc. Pharmacol. 13, 13-17 http://dx.doi.org/10.1097/00005344-198900135-00005

Received: December 21, 2011

Final version accepted: May 14, 2012 